\title{
ANALYTICAL PREDICTIVE REQUIREMENTS FOR PHYSICAL PERFORMANCE OF MOBILITY
}

\author{
Raymond N. Yong
}

Soil Mechanies Series - No. 31

December, 1972

\section{SOIL MECHANICS LABORATORY}

MALIILL URIVERSTTY

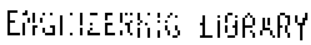

MONTEEAL LID, QUEGEC

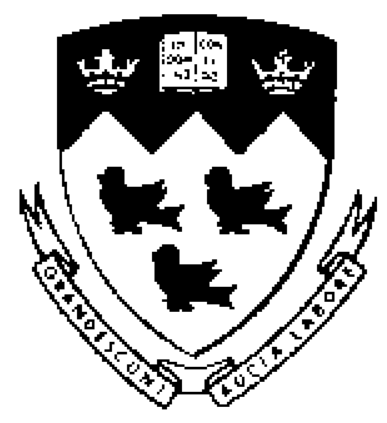

\section{MCGILL UNIVERSITY}

DEPARTMENT OF CIVIL ENGINEERING AND APPLIED MECHANICS

MONTREAL, CANADA

REPORT TO

DEFENCE RESEARCH ESTABLISHMENT, OTTAWA

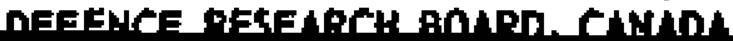

DEPARTHENT OF DEFENCE PRODUCTION, CONTRACT NO. OIGR70900SI SEAFAL NO. 2GRI.48 
ANALYTICAL PAEDICTIVE REQUIAEMFN:S PAR PHYSICAL PERFORYACE OP MOBLL:"Y

$$
\text { by }
$$

\author{
Raythond N. Yong \\ trofersor and Director \\ Soll Mechantes Laboratory \\ WeGill Univetsity \\ Hontreal, Canada.
}

For presentak10n at the 1972 Winter Meeting AMERTCAN SOCIETY OF AGRICULTURAL ENGINEERS

\author{
Conrad Hilton \\ Chicago, Illinola \\ Decerber 11-15, 1972
}

\title{
SUMNARY:
}

This paper examines the mechantes of vebiele-sot 1 Interaction in off-road mobllity problems with a view to evaluation of their relevance and rationality of the physical behaviour characteristics demanded by tie analyses and theorles, both for predictive and evaluation pucposea.

\section{American Society of Agricultural Enginears}

\section{Et,doseph, Michigan 49085}

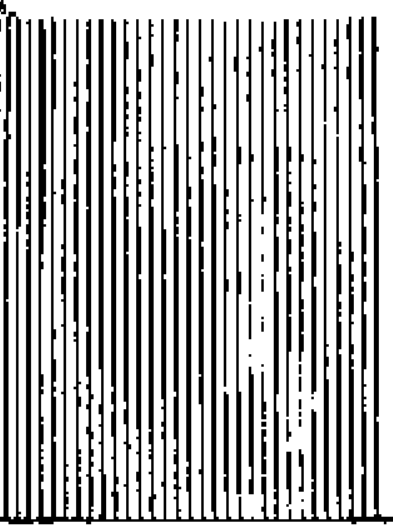

Paft. r prestenled belore ASAE neetings are considered to be the property of the Socluy in gereral. the Sociaty reserves the righl of lirst publication ol such paperg, in complette form However, lt has no objectuon 1o publication, in condenged lorm, with eredil to the socety and the aulhor, Permbsion lo publish a peper in lull may be recuested liom ASAE. F.D. Box 229, St. Joseph, Michigan 49086. The Soclely is

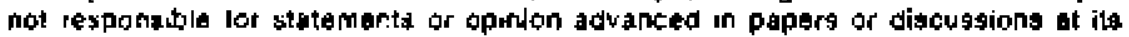
net:lings. 
MULYTICAL PREDICTIVE REQUIRRMENTS FOR

PHYSICAL PERFORMANCE OF MOBILITY

by

Raymond N. Yome"

INTRODUCT ION

The scudy of vehtele-soll tinteraction from the vietpoint of groundbearing ent forward potion capabilfty has tradtctongliy followed along the

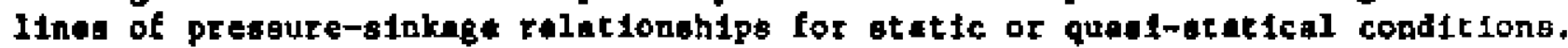
It 10 not pupriafig therefore to arrive at relationghipa for resistance to forward wotion of whele In terws of bearing capactly paraneters not unlike thog* In seotechntcal eogineering atability analjoeg. SJnilarly, conalderatlone In grouer studies yleld analytical expeeselong with almoat identically corresponding paraneters.

Since the intent of vehtcle-soll interection etudias la to provide 8 base for underatanding and analyelo of relevant parawetric influences and control, 1t becomes obvious that the physteal bedo for formulation of working relationghipa mat cloaely resemble the approprlate "field" attuaton. It 1s apparent that whilet gtat lc pressure-penetration tegta las performed previously] apasa bearins gtability, thetr abllity to reveal 1ike patterns of mobllity can be critically quest toned.

This paper examines oow of the fundarental physteal inceraction characteriatica eatablished between vehicle contoct unite le.s. Whel, grouser, te.] and soll - with a view to edtabliuhing the necessary component s for the analytical model. Compatibility and ofollarity betveen phyaleal and analyticel wodel are aeen to be the requirements for informed analyses and succestul predictlong.

\section{GEMERAL ANALITICAL REQUIREMENTS}

In arciving at a method for analysig of a typical wheel-goil interaction problem, the prinary ageumptions can include the tact that ctre deformabtlity can be suttably uccounted for by apociated changes in contact area and presaure. The tnteraction problem can thu be anslyzed by coniderIng the stabllity of an element of the supporting material. The essential requiretents reduce to:

1) Conpervation of linear nowentum - 1.e. the rate of change

Professor and Director, Soll Mechanica Laboratory. KcGlll Uotveretty, Montreal, Quebec, Conada. 
of momentul of a body 10 equal to the force acting on the body. The resultant forwulationa provide the equation. of potion, [differential equet lops of equilibrtur, etc.].

2] Congt 1tutive relationshtp - 1.e. Hohr-Coulonb or alternate appropriate fallure criterion.

3] Boundary cond 1 t Iono.

4] Cont 1 nutty.

Sone or all of the essential requirements may be used to seek a solution to the interaction probler - dependent on the requirementa For sophistication, flextbility and aceuracy conststent with the denand of the probles. The complexity of the interaction probles lo due in part to the nuber of factors and peraneters tovolved, and also in part to the interdependent relattonships established between many of the factors, e.8* -

1] Physical condtions - theel load, wheel surface, whee surface, wheel diameter, tire shape and stiffoess, treads, etc.

2] So11 parameters - Strength, density, type, constitutive behaviour, wolsture content, etc.

3] Interaction parapetere - Translationsl velectky, slip, dynamic sinkage, driving characterlatics, etc.

Dependent on assumptions made, analyses can be gimple or rigorous. By neglecting coil deformation and Inertia terms, and considering only 5 igid body forces, clasolcal theorles of soll mechantcs may be used. Resultant formulations are thus obtalned by gtudying the static equilibrlun of sone a tsuned geometrical configuration which satigf les the Mohr-coulonb condtion. Extension of the otatic analysis into beating atability congiderations provides for a higher order of accuracy - albelt still not necessarily precise or I Igorous.

With assumptions of plastic behaviour of sotl, 110it equiltbritn and bounded analyser nay be uged, By and large, all of the eagential roqutrements listed previcusly in term of fleld mechanica and conatitutive relationshipg are needed in arriving at a tracteble solution. The epectfication of boundary and Intelal conditions becones the cructal element In the solution of the problem. The varfous constraints attendant to the atated constitutive performance of the soll cannot be overtooked in the cholce of this tethod of analygig.

Departure from rigld requirements in classical plasticlty solutions begin with spectfication of non-1inear wotk hardenting theorleg for the constitutive performance of so11. This approach to reality is particularly desirable if nuterical techniques [finite eleoent or fintte difference] are to be used in geeking a solution to the interaction problen. The requirenent for linit equilibrlum 1o thus obviated with a known and specifiable constitutive relationsh1p. 
It 1s obviou that regardless of method of analysis chosen, 1.e. -

1) Stattc equtlibrium - tely Ing on elmple conservation of energy.

2] Qued-atatic analyoed.

3) Linte equilibrium - wth solution wethods in terms of upper and lover bounds.

4] Exact methodg - characterietic solution.

5] General field wechanicg formulation - wth solutione wought in terts of approxinate numerieal techniquen [finite difference], ot through varfational tboreng and solution: obtatned with fintce element techniques.

accuracy of analyale and prediction can be obtained through compatibility and conalotency of fleld pexforrance with analytical model.

\section{CQYPATIBILITY AND CONSISTENCY}

\section{Wheet-Sofl Energy Losses}

Coosider the wheel-soll interaction phenomedon shown in Figure 1.

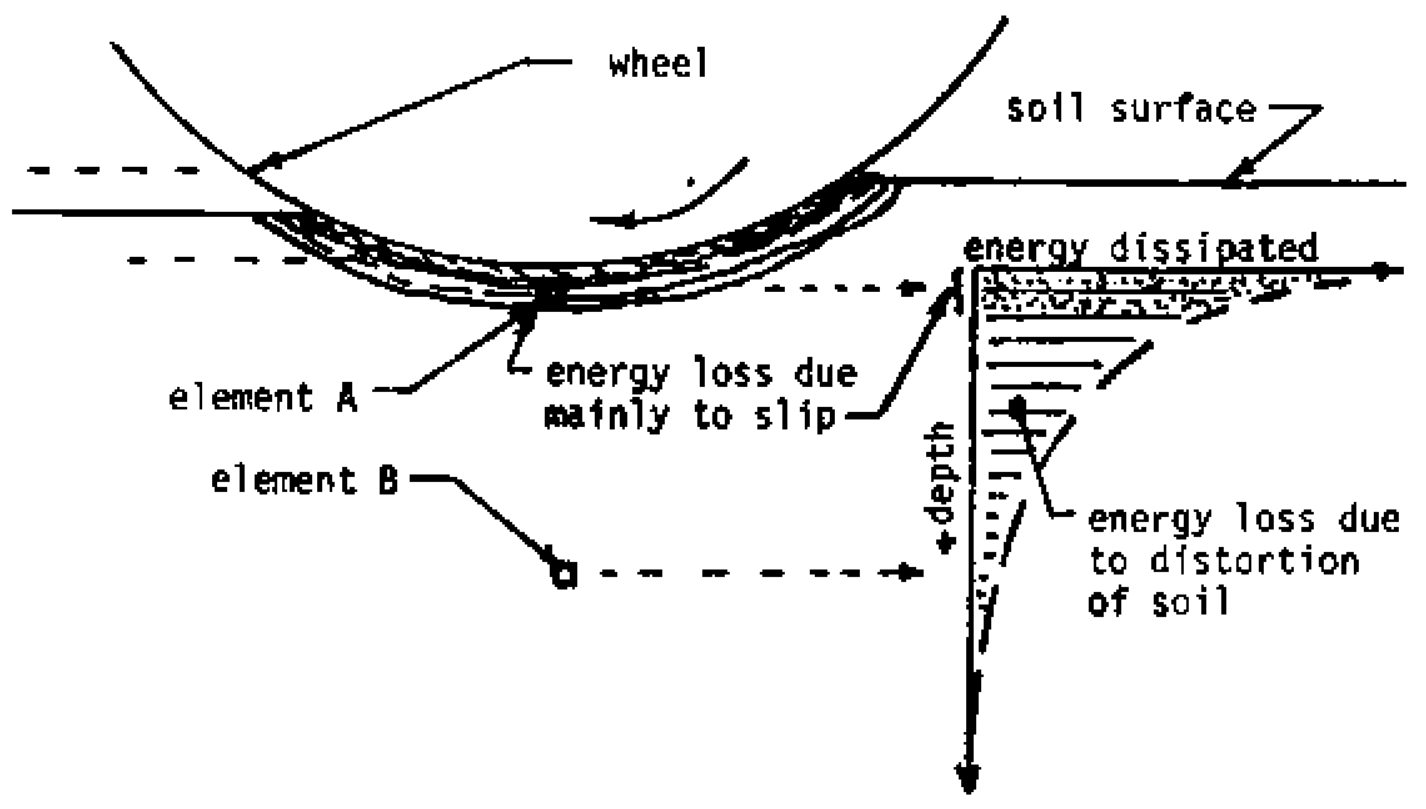

FIGIRE 1 - EHERGY OISSIPAT ION IN SHBSTRATE DUE TO IMTERACTIOH 
It Iq evident fron Figure 1 that above the aelf propelled point, tokel enerty 10ge becoese eneltive to allp constderekion. The two clements $A$ and $B$ In Figure 1 show that two separate nechaniong of shear dintortion are operative - In the case of alip perfotmance. For element A, h1sh ohear distortion existe if el1p between theel and ooll occura, Iffit

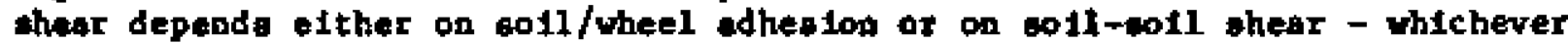
1. lesser. The end retult is analogous to viscout thear resietance.

Elenent $\mathrm{B}$ on the other hand it subject to shear digtortion arising

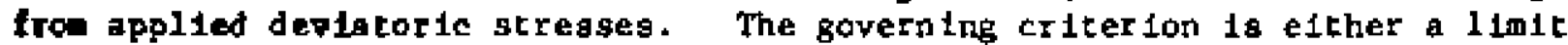
shent coodicton or an operative aheat below the fallure value. A work hardeniag coontitutive nodel appears to be most applicable.

In cased vista alfp it not particularly large, the performance of clesent $A$ 1s not unlike that of $B$. The transition of elemencal performances ditingutahing A fron B to neither abrupt nor distinct. Slip energy lags dien very repidly at diatancea not far removed from the wheel gurface.

In ppeculating on the lind of analytical model that might be used to describe the interaction thown In Figure 1 , it would be ingtructive to recall some direct performance characterics. Confirmation of the phyelcal nodel show ta figure 1 ig desoagrated In Figure 2 .

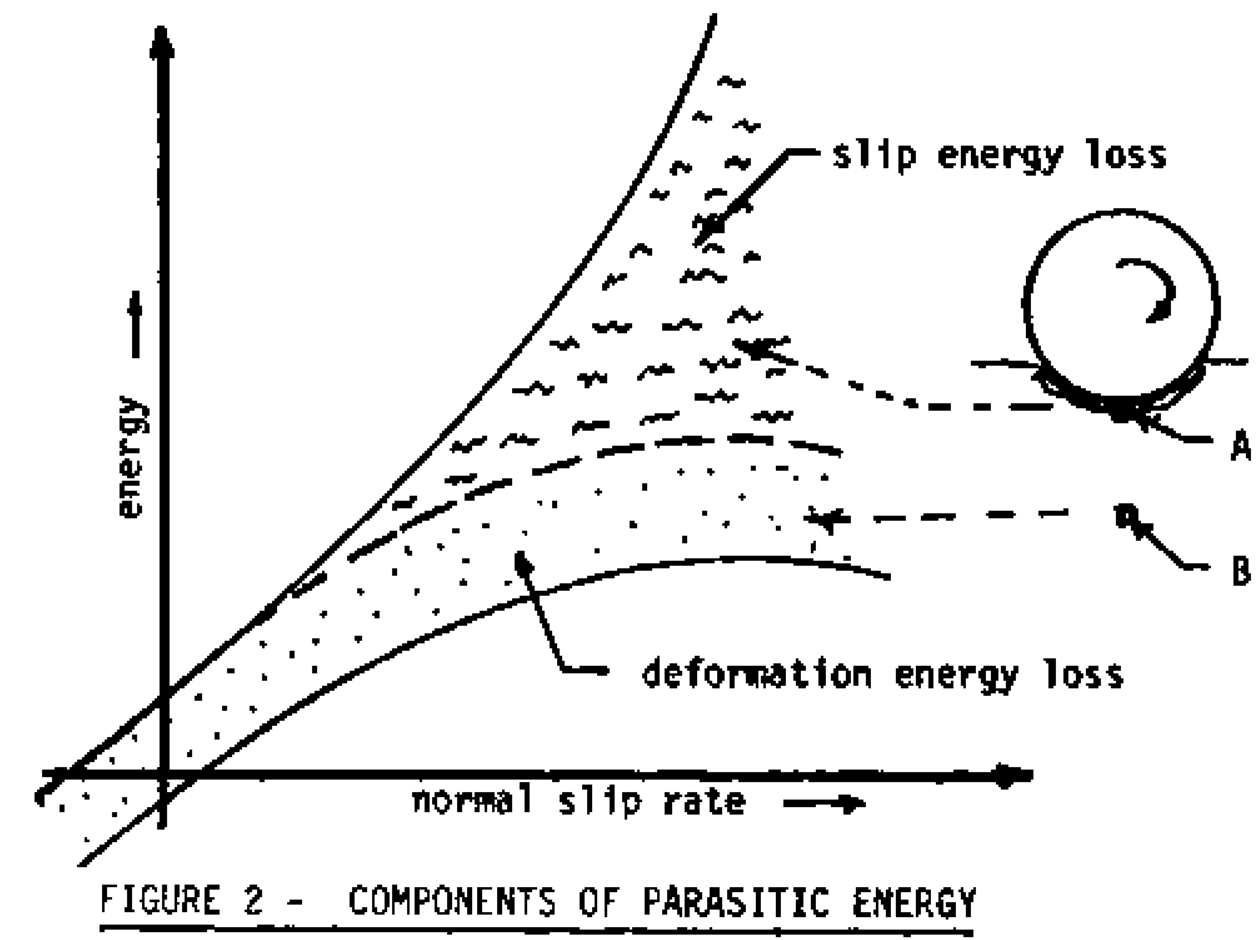


Yong and Webb [1969] have shown frod controlled coll bin teets on poft clap that parastelc energy componente as obown in Figure 2 can be evaluated directly from meapuremente of subatrata deformation and diatortion. Th10 confitwe both the mechanistic forwulations shown in the schenatic diagram of Higure 1 , and the fact that direct interdependence colat 1onship between abovestound and in-ground paranetero do exist to control final output performance. The relevance and importance of interaction and interdependencies ore best dewongtrated in terms of: [a] contact preseure, [b] dyoanic sinkage [robound], and [c] substrata perfornabe.

\section{Theel-Sotl Interface Performance}

It physical meagurements of contact preseureg and stresses, two afsteng are used.

1] Pressure gauges embedded in the 6oll.

2] Presaure gauges fixed to the wheel contact surface.

Since the first syotem to not reliable in view of the physical displacement of the ambedded gauges, the second method to nore counonly used. By and large, the pressure gauges vill only sense preasures acting directly on then [1,e. direct normal conpreselve preseures]. Figure 3 shows a comparison between measured and theoreticaliy computed nomal pressure at the interface - valng meagurements of subsoll performance [Yong and Windisch, 1970].

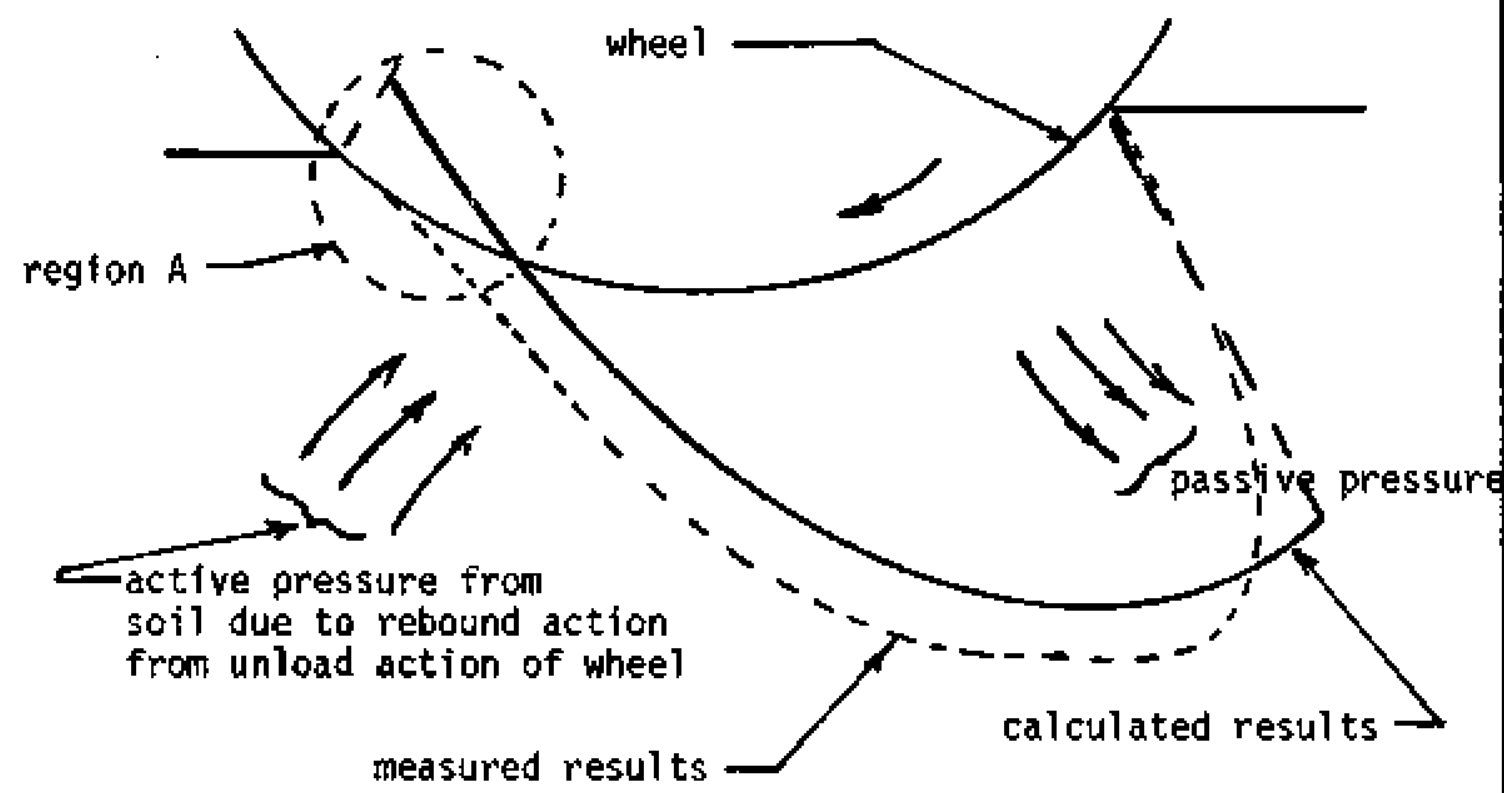

FIGURE 3 - MEASURED AND CALCULATED INTERFACE PRESSURES 
Except for a clear and diotioct reparation of soll frow tha contact ourface in region $A$ at show in Figure 3 , the preggures on the whel surtace thould efther be pooftive lcoapresstvel or petative [tenelon]. Howerar, stoce the pressure guges cap only wepse compresalve perforance, due etther to -

[a] conpreseive theal action Into soll - goil is in paeatve etete,

[b] active soll ection on to contect wurface tn tebound action as weel beglat to unload In ite forward motion,

16 14 evident that tenston value ore not recorded, The tengion valuea can occut due to adharence of sot1 to whel auface becaude of and in addicion to the low rebound charecterlatics of coll - 1.e. Wheel unload 1a fater than rebound behaviour.

Frow neaburements of inetentaneove soll deformation [conpreselon and robound] In wil bin teste, tt has been thown [Yong and Windiach, 1970] thet conputed interface pressures compere well with applied pressures. The particular solution technique chosen relled on evaluation of limit equilibrium conditlons vith a Treeca type fallure condit $10 \mathrm{n}$. Tenelon volues are thus oot axcluded in regtion $A$ - if such valuea are lndeed repreaentative of the behavlour of the oubeoll duriag vhet unloading. It 18 clear therefore that the 11kelthood of such kinds of perforwance, not gecessartly senced by prestoure teaturemente, wot be bullt into the analytical model devieed to provide an analygis of the Interaction problem.

\section{Gouger-Sotl Performince}

Delineation of parantic energy componente and interfacial behavioral apects in grouser-wo1l interaction it not engily accomplished. Resultg

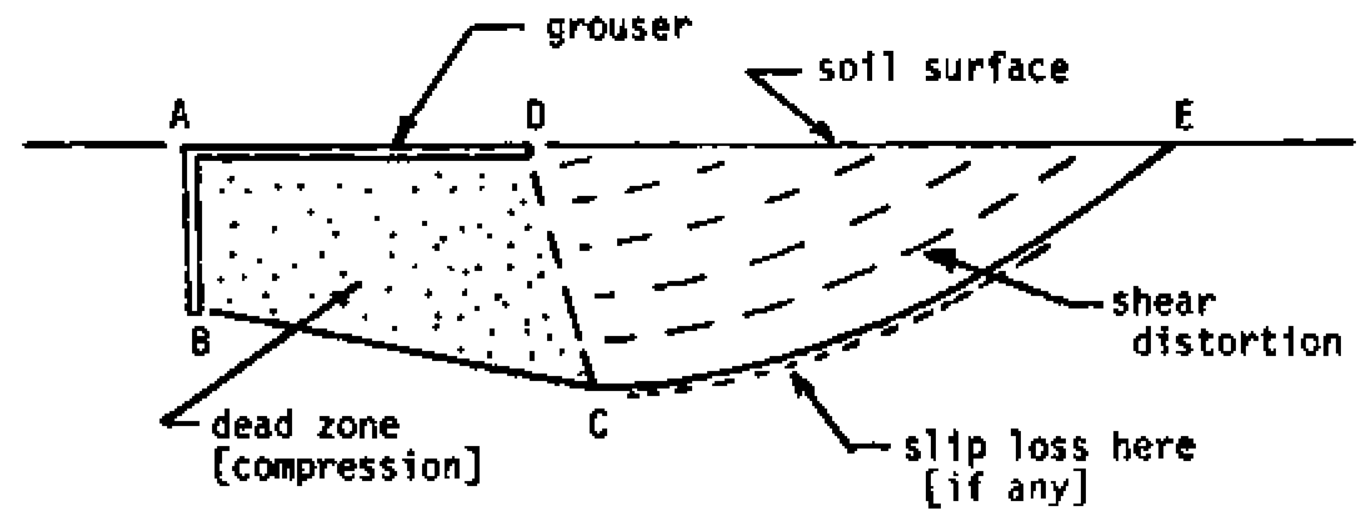

FIGURE 4 - GROUSER-SOIL INTERACTION 
teported by Yoog and Sylveotre-Williema (1969) Indlcate that compresaton of coll occurs in the 'Head' zote prior to aheer ditcortional fallura [Figure 4 ].

Unlike the vhel-eotI 1nceraction problen, there appeats to be vory little alip energy loeg vis-a-vis grouser-goil interfactal performance. [s1ip loos in the track oyotem however still exista]. The leading [vertical] dge of the grouger cerves to provide the lateral thrust in the coll, thus obvinting olip lose diteotly in the grouser-eoll zone. Whatever mintmal altp energy lose extate, vil in all probability occur in the slip surface sore under bigh rates of grouger traverse,

Thus, In terms of analytic modelling, the prime requirement is in regard to a proper deacription of the perfortance of the "dead" zone. For afmplicity aceutptione of zero energy lose in the "dead" zone are nade and lint theorens applied to eeck a tractable solution. Thus, sone ABCD 19 conotdered to be rigid and zone CDE constitutes the region of analycic intereet. In actual practice, three Immediate problems exiat -

1) Location of point C [in Figure 4].

2] Compregeton behaviour of 6011 in zone $A B C D$.

3] Determination and apecification of the phystcal boundary condition - at the grouser soll Interface and at DC.

By and large, becauge of the relative simplistic block behavioral pottern show in Figure 4 for prouter-poil inceraction, the at ractivenese for gtacte equilibriun analyols using rigtd body analogies is obvtous. Repult. show however that troderprediction of thrust occurs becauge enerby loss in digtortion of soll in zones $A B C D$ itd CDE, and shear energy losg at interface $C D$ are not accounted for.

In simulating trangvere motion of the grouger, it is combon practice In laboratory axperimentation to control -

[a] depth of grouser traval - 1.e. variable vertical force resulting therefrom,

[b] applied vertical force - 1.e. varlable depth of grouser motion.

The reaultent thrust developed for aituation [a] 1a obviousiy differeat frow that of [b] - due to the different boundery coadttions developed. Fong and Sylvetre-W1111ame (1969) show from expertmentation and theory that cituation [a] produces a greater thrugt = so long as both grousers (1.e. for [3] and [b]) start of at the same equilibrius elevation. It is however, not difficult to produce higher thrusta for gituation [b] as compared to fa] If intelal conditiong are succesafully manipulated.

The actual field problem however involves -

1] Multiple grousers on a IInk or belt system,

2] Netther 61tuation [a] nor situation [b] as total exclusion performance characteristics - 1.e. Neither vertical loada not elevations are controlled. 
Thus prediction of mobllity for traek syaterg based on atrgle grouser anelyals must sultably account for multiplicity of grouber action together wth inadequacles of track morphology. Track anslyele however constitute a separate problem and $1 s$ not covered within the acope of thie otudy.

\section{Then1-Soll and Grouser-So11}

Predtctive Requlrenent 6

It is apparent that for analyelcel ond predictive purpoese, the bustc requireoents for the properties of the analytical model relote to -

(a) realistic spectefcation of the load and unload conatitut ive performance of soll - not necessartly confined to yleld or 1101t equilibrilu,

[b] a proper apprectation of the phyalcal boundary conditions 1.e. Interface characteristica and Interaction,

[c] an Inforwed knowledge of the phyolcally active and paative constraints.

\section{ANALYSIS AND PREDICTION}

The diatinction between analytical and ptedictive requirements can t) thea be very subtle. However, In general, rigoroug analyses are deanded If aucceseful predictione [based on the analytical mode1] are to be made, In the interaction atudy, It is asoumed [and reasoned] that the forcing function [1.a. whel or grouser load pattern] and the regponge function [1.9. col] reaponse beheviour] are oultably related and wodified through wone correlating Eunction. Thus, if one can desctibe or evaluate the response function charactertetics, and if the correlation functions are known, it becoued obvious that the ourficial load parameters will be identified and accounted for.

\section{lended Plate Analosy}

The simple analogy of a loaded plate [for simulation of wheel loading] ol like contact area produces preasure-sinkage relationships not unlike those uned in conventional bearing atablitty analyees. Plgure 5 shows the required reaponse frot the application of the plate model. Th1s 1a cotpared to direct observetions [Yong and windiech, 1970] on actual subsoll performance for towed vhesle.

The one clear requireent in the plate nodel is that compression behaviour occurs throughout. The resultont formulation in cerms of a semiempirtcal plagticity solution yields the pressure relationahtp - 
soll surface loaded plate

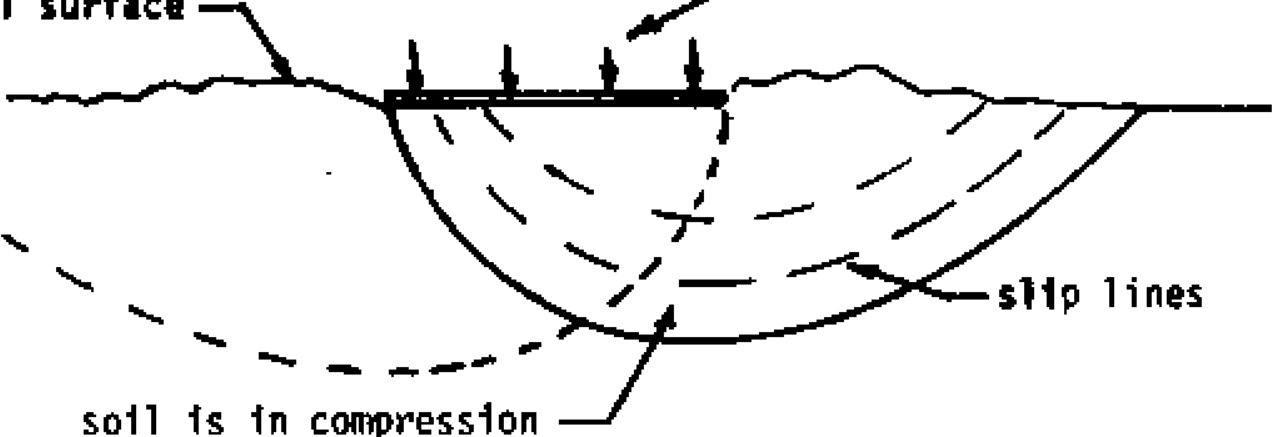

$\downarrow$ LOAOED PLATE ANALOGY

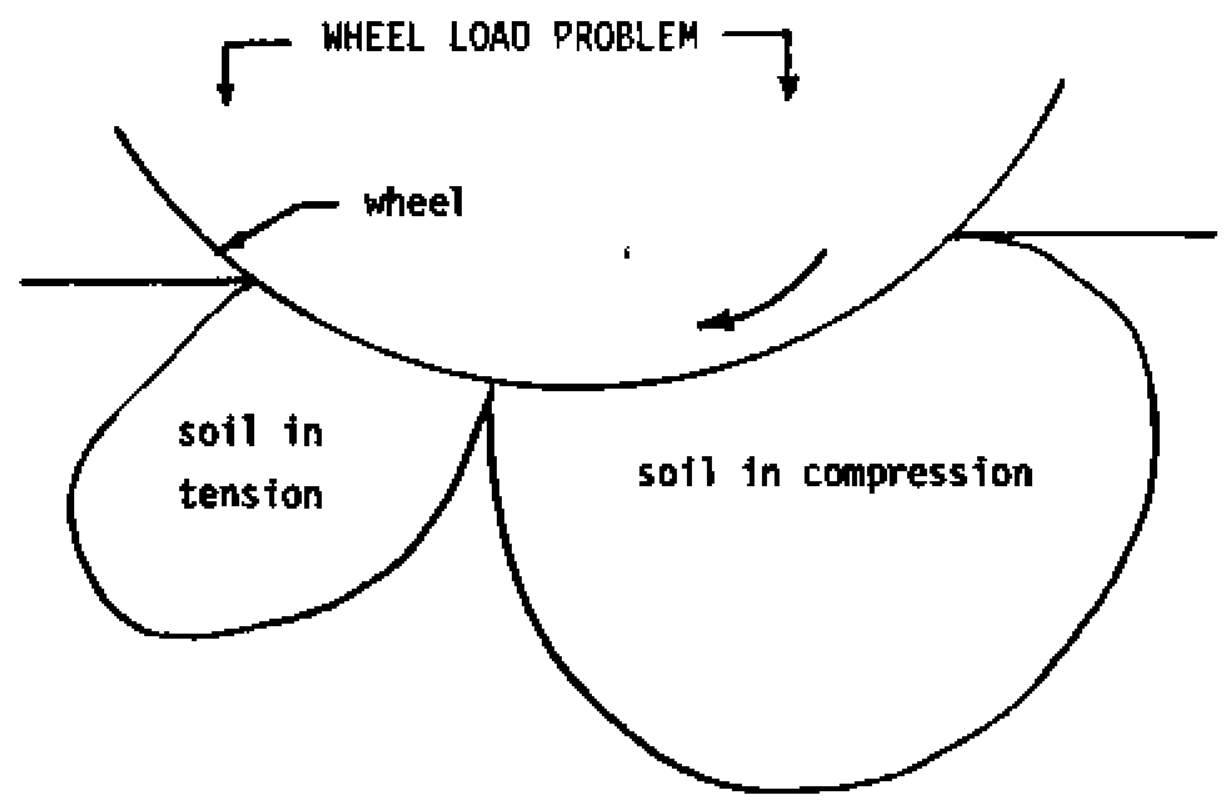

FIGURE 5 - LOADED PLATE ANALOGY AND WHEEL LOAD 


$$
q=1.30 \mathrm{~s}_{c}+0.6 Y b \mathrm{~s}_{\mathrm{Y}}+\mathrm{YDH}_{\mathrm{q}}
$$

vhere

$$
\begin{aligned}
& q \text { - pregeura on plete } \\
& \text { c coheaton } \\
& \gamma=\text { notl density } \\
& \text { b - breadth of loaded plate } \\
& \text { D = depth of loading plane }=0 \text { for surface loading }
\end{aligned}
$$

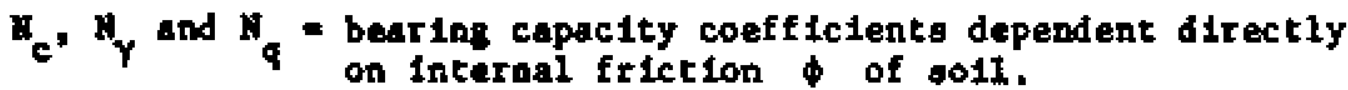

For a surface loaded plate, ance $D=0$,

$$
q=1.30 \mathrm{~s}_{\mathrm{c}}+0.6 \gamma \mathrm{B} \mathrm{s}_{\mathrm{Y}}
$$

The andogove andyals for the wheel gives [Reece, 1965]

$$
p=\left[K_{c}^{L} c+K_{b}^{L} Y_{b}\right]\left(\frac{\pi}{b}\right)^{n}
$$

vhere

$$
\begin{aligned}
\mathrm{p} & =\text { pressure } \\
z & =\text { sinkage } \\
\mathrm{K}_{\mathrm{c}}^{\mathrm{t}} \cdot \mathrm{K}_{\mathrm{f}}^{1} \text { and } \mathrm{n} & =\text { sotl paraneters }
\end{aligned}
$$

The similarity between $k_{\phi}^{2}$ and $k_{c}^{2}$ co $k_{\gamma}$ and $k_{c}$ 1s obvious. Bearing in wint that solely compreaston behaviour is oxpected, the rebound performace of the sotl during wheel unloading is thus oot considered as part of the prediction requirenent. Deviation between prediction and performance can be due in part to this apect. For good predictability of wheel perforonce uging the loaded plate nodel, it it easankial that -

1] Slip ig kept to an 1nsignificant quantity.

2] Sol1 propertles are ouch that rebound performance is inimal or 1neignificant.

3] Wheel movement is slow.

4I Wheel surface and load distributions are uniform. 
From the above, it can be deduced that if olip perfotuance can be evaluated perhape eone degree of oucceas can be achieved in fortulating a conbined model which would incorporate thie loss. In addition, It would -ppear that both load and unload perforwances ouet also be lncluded In the analy 15 . It is clear that the requireaente of the plate model do not render compatibility between physical and analytical models - except for a tery narrow range of wheel perforwance. Both forc1ng and response functions are so severely conetrained that generalization la not poselble.

\section{L1mit Equilibrium Model-Grouser}

By and large the analytical podela used for lintt equilibriut colutione generally agsue the admiasibilty of the Hohr-Coulomb or Treaca eriterta. Soll beharlour - 1,e. reeponse function characterietle, te thue deftned and analyzed in regard to the forcing function in the framework defined by the boundary conditions.

In the grouger-soll Interaction problet [ag ohown 1n F1gure 4], the 1Imit equilibritum approach has been euccessully ued by Yong and SylvestreHIlltang - with ageunptions of -

1] R1g1dity of block ABCD.

2) Full fallure development in the entire mage defined in zone CDE.

3I Insignificant volume change in ABCED.

The analytical model by Yong and Sylvestre-W1lliams (1969) 1s shown In Figure 6.

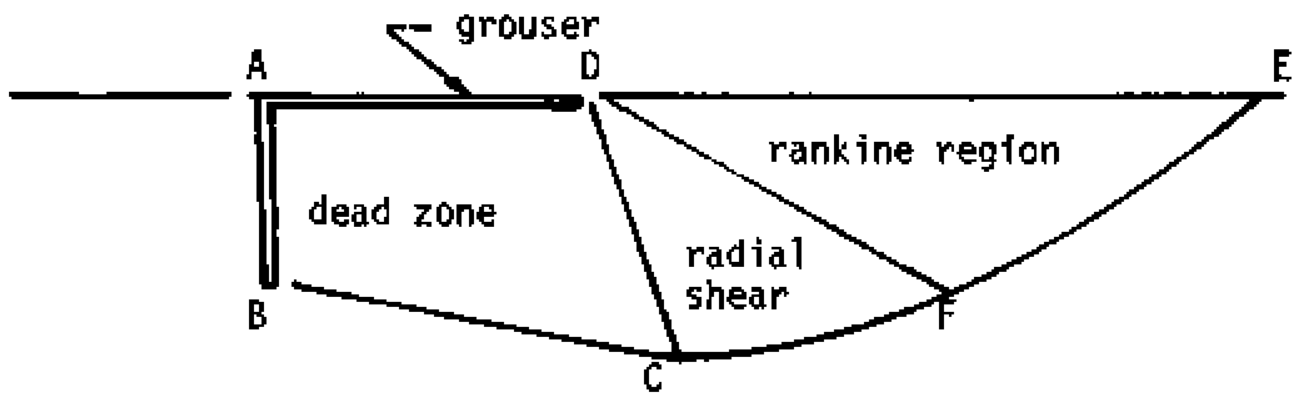

FIGJRE 6 - ANALYTICAL MODEL FOR GROUSER-SOIL PROBLEM 
Defintng $S(\theta)$ as the atrese function in relation to the gean atregs $0:$

$$
\sigma=\frac{\sigma_{1}+\sigma_{3}}{2}-\rho \operatorname{srs}(\theta)
$$

vhere

aubecipta 1 and 3 - asjor and minor componenta

$$
\begin{aligned}
\rho & =\text { density } \\
g & =\text { gravitational acceleration } \\
r & =\text { radial distance } \\
\Psi^{\prime} \text { and } b & =\text { as shown in Pigure } 6
\end{aligned}
$$

The equationg of equitibrium, in polar coordinate form [with origin at polnt DI are vitten as:

$$
\begin{aligned}
& \left.\sigma_{r}\right]=0\left[1 \pm \operatorname{\theta in} \phi \cos 2 \psi^{1}\right] \\
& \tau_{r \theta}=0 \sin \phi \sin 2 \psi^{\prime}
\end{aligned}
$$

Combinting Equation (4) with the whr Coolonb condition and regrouping, ope obtalnat

$$
\begin{aligned}
& \frac{d \psi^{1}}{d \theta}=\frac{\cos \theta-\operatorname{\theta in} \phi \cos \left(2 \phi^{1}+\theta\right)-s \cos ^{2} \phi}{2 \sin \phi\left(\cos 2 \psi^{1}-\theta \ln \phi\right)}=1 \\
& \frac{d S}{d \theta}=\frac{\sin 2 \psi^{1}-\sin \left(2 \phi^{2}+\theta\right)}{\cos 2 \psi-\sin \theta}
\end{aligned}
$$

Solution of Equations (5) Hil allow for computation of $S(\theta)$ and finelly $\sigma$. The boundary condttone ascrthable to the Rantine zone at point $F$ are: 


$$
\begin{aligned}
& S=\frac{\cos 0}{1-\sin \phi} \\
& \psi^{\prime}=\pi / 2-\theta
\end{aligned}
$$

and ac $C$ is

$$
y_{C}^{1}=0.5\left[\pi-8-\arcsin \frac{\sin \delta}{\sin \phi}\right]
$$

where

$$
f=\text { friction angle between soll and grouser wall }
$$

The value of $s$ at $c$ can only be obtained through an lterative cechotque.

The theorettcal alip Ine field can also be eveluated and compared wth sctual slip surfaces from experinentation. In applytig the model shown in Figure 6, using the method of characteristics as the exact golution techrique, Integration of $\sigma$ [fron $S(\theta)$ ] over the length of CD will provide the thrust on the grouger. Confituation becween andycical notel predtction and phyolcal perfermance of a single grouser can be obtatned by:

1] Matching phystcal faflure aurface in soll due to erouser act lon with thearetically conputed fallure charactetistic [Yong and Sylvestre-Wiliams (1969)].

2] Match computed Integrated value of $g$ with physical values.

Thus for eraple, the results shown in Figure 7 show individual grouser tests in eand at controlled depth and vertical atress. Comprigon between lintc equilibriun wodel predictions [Hegili] vith predictions from previous clogetcal extenston of loaded plate analogiea [Bekker (1960)] show that the simulated Inclined bearing place relat 10ushipo do not adequately predict actual performance. The standard relatiooblpo used are [Bekket (1960)]: 
$H=b\left[n_{c} L c+Y n_{g} L z+Y_{Y} L^{2}\right] \sin \theta$

$W=b\left[n_{c} L c+Y n_{q} L z+Y n_{\gamma} L^{2}\right] \cos \theta$

Where

$L=$ grouser length

$b$ - grouser width

$z=$ sinkage

$W=$ vertical load

$\mathrm{H}$ - horizontal thrust

c = cohesion

$n_{c}, n_{q}+n_{Y}=$ dimenstonless sofl parameters dependent on soil friction angle $\phi, \theta$ and $L / h$

$h=$ grouser depth

5 - sfarlated inclined footing angle dependent on sinkage.

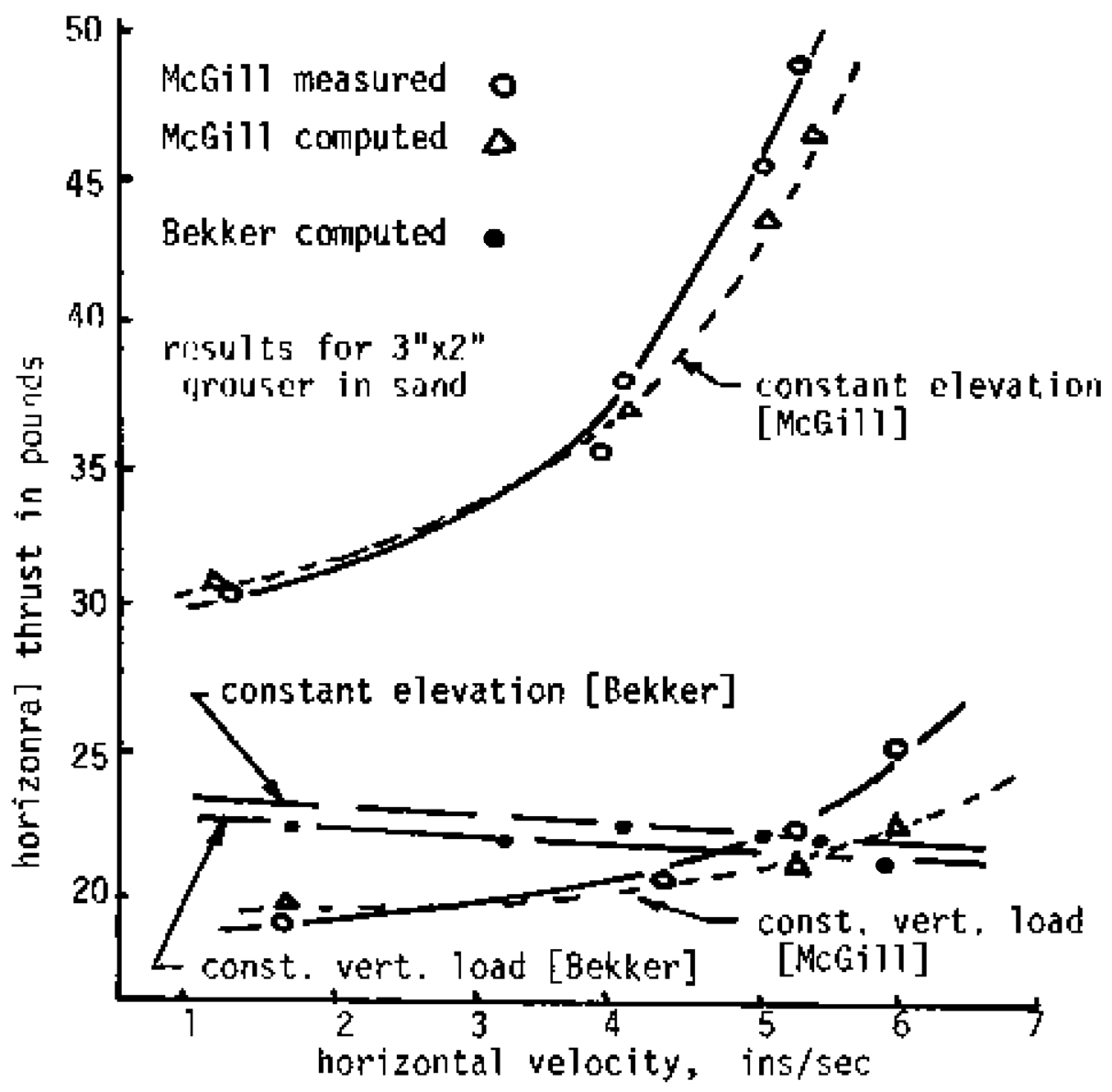

FIGURE 7 - PREDICTED AND MEASUREO FORCES ON GROUSER 
The dimenatonless soll parameterg ohown in Equation (8) are in esance entlar In fornat and philosophy to those generated for foundacton stability and pressure alnkage relat lonahipa for wheels - as discusped previouoly. It is thue not sutpriaing that the linit equilibriug analytical codel thould perform better atnce te has a cloaet apprectacten of the actual physica of the grouser-tateraction problem. Tht: however does not deny the vet of the inclined plate model [Equation (B)]. On the contraty, Equat $10 n$ (b) It useful ingofar as oimplicity and expedient uage are concerned.

\section{Leic Equ Llibrium Model - Wheel.}

Much in common [In terms of phllosophical formulation] with the trouser-soll interaction problem, the 1 intt equ1librium nodel analytical approach to the whed-soll finteraction phenomenon treats the status of the bearing coil uthin the context defined by the boundary conditions. The opecific constraints of this appronch [hindfoch and Yong (1969), Yong and Windich (1970)] tsing the method of characteristics as the solut ton technique relace directly to:

1] Total limit equilibrium.

2] Instgnificant volute change,

3] Definable boundary conditions.

The cagting of analycical formlat lons is noc unl ike those developed for the Brouser problem, - using the stress characteristic approach, assuming a drect relationship between stress and strain rate. By phystcally reaguring stbsofl deformation with time [as is poselble In controlled soll bin teata] ti 1g apparent that with approprlate constitut ive relationships and agsoctated flow laus, the instantaneous stress fleld beneath a moving wheel cen be mapped. The forcling function at the boundary - 1.e. whel-sofl 1nterface can thus be obtalned. Figure 3 ghows the calculated presgure diatr 1bution cbealned directly by atraln-rate measurements in the soll [1.e. response function deternination] and calculacing che inpulse function producing the observed atrain-rakes. The seemingly abrupt atresa contour at the two ende is a defictency of the anolytical model - which treats che streos atcuation implicitly in terms of a discontinutty across the IImit fallure characteriatic. A less abrupt contour appears to be a nore reallatic eppreclation of stress or pressure at the interface.

Figure 3 demonstrated the possibility of tenston valtues in soll belng teveloped fn view of unloading of the soll during passage of the wheel. Aa patnted out eaclier. this phenowenon wight not be directly detect ed by presgure gauges enbedded in the whel. The liattations and conetraints of the onalytical model are thus traceable ditectly to the tequltements of 11 mit equ111briw theory and the constratnts associated with spectfication of the conatitut ive relat fonshtp for the subsoll. 
Energy wodels for analyats and prediction of vehicle-soll fnterattion perfomance will rely on one's ability to measure [or determine] response function performance. As in the cise of $11 \mathrm{mit}$ equilibrium models, the energy method utilizes forcing and response functions. In this inctance, however, the two functions are fitted [multiplied] together to produce the work or energy function.

Inlike the linit equilibtlun apptoach, the energy model does not require that limit or yleld be necessarily reached fn the stressed subsoll. This however demands that proper and admisstble constitutive relationghip be defined. This requitemenc can be moot demending. Using a yleld function formulation, Yong and Webb (1969) have applied the energy approach and have obtained cypical resulta of parasitic energy ag shown in Figure 2.

\section{Finlte Element Model}

In recognizing the actractiveness of toore realiatic analytical nodelling of the vehicle-soll inceraction problem, tedious solution procedures have heretofore restricked implementation of what is essentially a complex boundary value problem. With the development of machine computakional alds, growth in numerical solution techniques have allowed for development of oore realistic modeling tools. In the fintte elenent anblyala of the wheel-sotl problem for example, Yong et al. (1972) have tceated the subsoll as a non-1inear elastlc strafn hardening materfal aubject to boundary conditions of an Incremental teturn, thus permitting calculitions to be made for description of the growth of stresses within the loaded soil from lnitlal to final states - slmulating preclsely the load and unload characteristics of a moving wheel. Thus the transtent loading problem of a wheel is now treated where machine computational techniques cen be uged with great edvantage. The resultant trangtent gtress field in the subsoll to solved as a sertes of equilibrium gtresa and displacenent fields whth the time span of Interest.

It mist be noted that whilgt finte element analyses using the simple loaded plate analysig may be used, [e.g. Perumptal et al. (197I)] the tnherent testrictive linttations associated with the plate analogy will prevall, Transient loading with glip developtent is the proper and necesgary requitement. In applying the finite elenent solution technique, use of the principles of variacional calculus ensures that ninioleation of the Integral fot of the governing principles rould provide for the closest avallable solution to the problem at hand. The Lagrangtan formulation for forces acting on the nodes of the descrlbed trangular elenents [Figure 8 ] to obtain the required displecenent tor nodal equilibriun would be given ag:

$$
\{\psi]-\int_{v} \rho[S]^{\mathrm{T}}\{q\} d v+\int_{A}[S]^{\mathrm{T}}[\bar{\rho}\} \frac{d \vec{A}}{d A} d A-\int_{v}[\varepsilon]\{\sigma\} d v
$$


where

$$
\begin{aligned}
& {[\text { ] colum vector }} \\
& \text { [ ] - matrix form }
\end{aligned}
$$

mperactipt $T=$ transposed that $\mathrm{r} 1 \mathrm{x}$

$\rho$ - dengity

$v$ - volune

A - area

aperactipt bar * deformed atate

(q) - body forces

[S] - shape function defining digplacement at any point within element with cerpect to diaplacement at nodal points.

[e] = strafn displecement relation

a. stregs

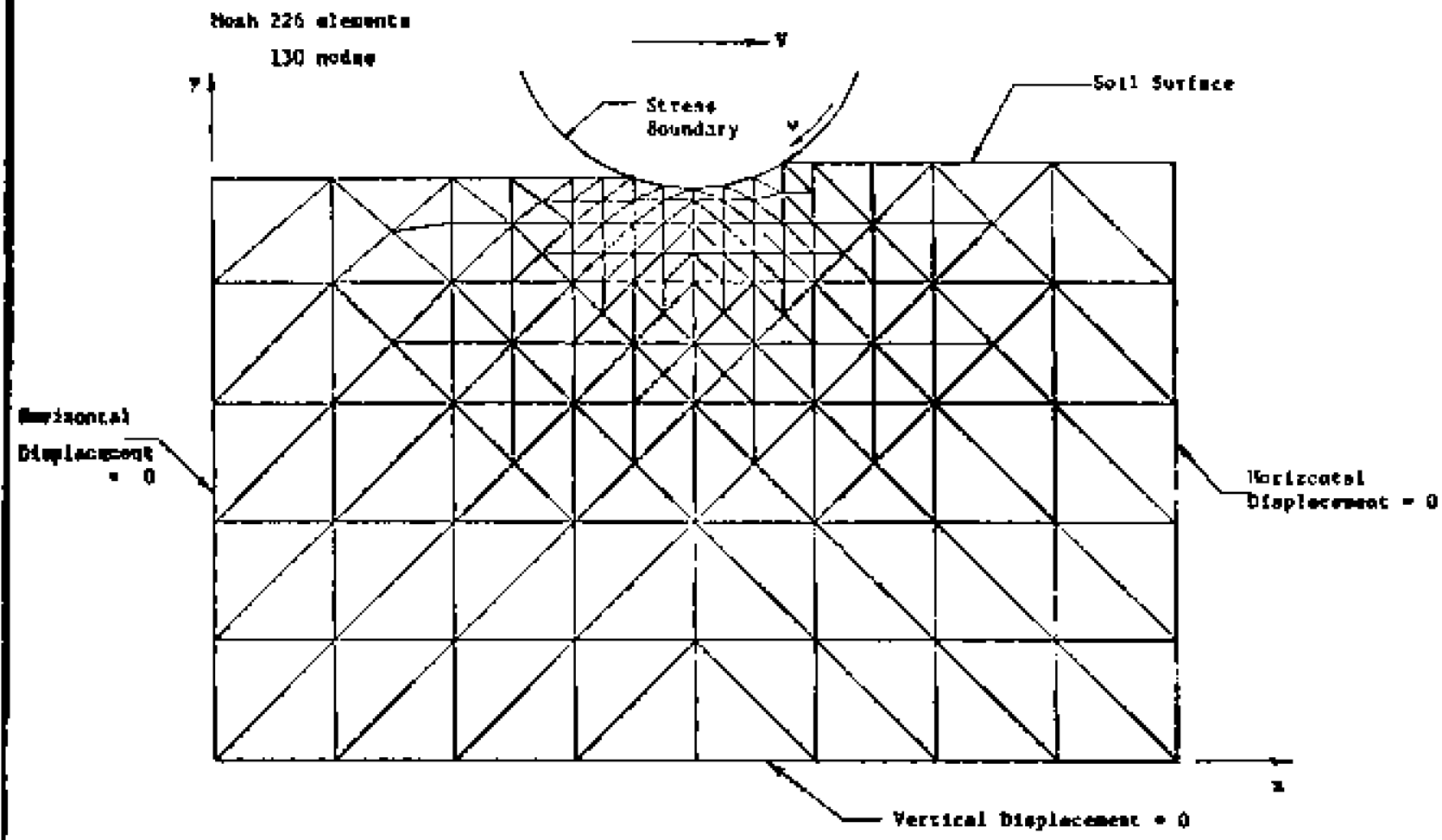

FIGURE 0 - FINITE-ELEMENT MESH FOR WHEEL-\$OIL PROBLEM 
Obvicusly, one of the key elemente in Equation (9) to the strain dioplecentent relation [e]. This io Integral to the evaluat loo of the conotitut Ive perforthace of the soll and tts partictpation in the vehiclecoll Interact ton problea. Applying the appropriate variationel technique, the fincl relationshis is thus given as:

$$
d\left[t=\left[x_{T}\right] d[\delta]\right.
$$

where

$$
\begin{aligned}
{\left[k_{T}\right] } & =\text { tangential stiffness } \\
& =\left(\left[k_{0}\right]+[k]+\left[K_{L}\right]\right)
\end{aligned}
$$

abscripts o, $L$ and $o$ - emaIl displacenent, large displacenent and atress level dependencies respectively.

is d deplaceoient

The boundary conditions applied to the system must realistically account for the entre load-unload equence typiffed by the tranelent wheel proble. Troblems of typifying interface performance characterietice ced be approached in view of tdeal charactertation as solution techniques. The colution to che problen is presently belng undertaken and w11 be reported at laker thage.

\section{COHCLUSIOHS}

The need for a close stmilartty between physical and analyt lcal nodela is apparent. In applying analyt lcal modelling rechniques, it is esgentlal that proper apprectation of the constitutive performance of the materlal and boundary conditions be obtalned and subequently applied. The approprlate framework defined by using realistic olnilarities between physical and athematical boundary conditions will ensure a higher order of predictabllty with the developed analytical model.

\section{ACKNONLEDGEENS}

The material Input into this paper has been derfved through research contract study under project Inttlation wth the Defence Research Eatablishment, Ottawa [DREO] and funded through the Department of Supply and Services. 


\section{BIBLLOGRAPHY}

1) Dekker, M, G. (1960) "Off the Road Locomotion" Untversity of Michigan Presa, Ann Arbor.

2] Peruapral, J. V., Liljedahl, J, B., and Perloff, W. H, (1971)

"A Nutrertral Method for Predicting the Stress D1atribution and Soll Deforation under a Tractor wheel" Journal of Terramechantcs, Vol.8, No.1, Pp.9-22,

II UInd 1sch, E. J, and Yong, R. H. (1970) "The Determ1nation of SolI Strain-Rate Behaviour beneath a Moving wheel" Journal of Terratuechanfes, Vo1.7, No.1, pp.55-67.

4] Toog. R. N., Fattah, C. A., and Hama, A. W. (1972) "An Analytical Solution Technique for Machine-Soll Interaction" Report No. CR-72-I.

51 Yong, R. N, and Sylvestre-W1llians, A. (1969) "Analys 1s and Prediction of Grouger thruse on Sand" Soll Mechanics Series, No. 26, DRED (Geophysice) 33.

6] Tong, R, N. and Webb, G. L. (1969) "Evergy D1ssipation and Drawber Pull Prediction in Soll-kheel Interaction" Proceed1nga, Third Internat fonal Conference, I.S.T.V.S., Vol.1, Essen, Gerrany.

7) Yong, R. N, and windiach, E. J. (1970) "Determination of wheel Contact Stresses from Measured Instantaneous Soll Deformat fons" Journal of Terramechan1es, Vol.7, Nos.3 and 4, pp.57-67. 